\title{
Lecturers' and Students' Profiles and Perceptions on the Implementation of Online Learning Evaluations During the Covid-19 Pandemic
}

\author{
Dwi Mardhia* \\ Faculty of animal Science and fisheries \\ Universitas Samawa \\ Sumbawa, Indonesia \\ dwimardhia@gmail.com
}

\author{
Fahmi Yahya \\ Faculty of teacher training and \\ education \\ Universitas Samawa \\ Sumbawa, Indonesia
}

\author{
H Hermansyah \\ Faculty of teacher training and \\ education \\ Universitas Samawa \\ Sumbawa, Indonesia
}

\author{
Hairunnisyah Sahidu \\ Faculty of teacher training and education \\ Universitas Mataram \\ Mataram, Indonesia
}

\author{
G Gunawan \\ Faculty of teacher training and education \\ Universitas Mataram \\ Mataram, Indonesia
}

\begin{abstract}
The implementation of online learning evaluations is better choice during the Covid 19 pandemic. Hence, this study aimed to describe the profiles and perceptions of lecturers and students at Universitas Samawa regarding online learning evaluations in the even semester of 2019/2020 academic year. This study applied a survey method involving lecturers and students as the respondents representing all faculties at Universitas Samawa. The data were obtained from questionnaires using the Google form application and from focus group discussion. The data were analyzed descriptively. The survey results showed that online learning evaluations used several platforms wherein WhatsApp was the most dominant platform chosen by lecturers. The obstacles that most often arose during evaluations of online learning outcomes were the problem of internet connection and the level of students' understanding of the tested materials. Lecturers and students agreed that online evaluations were not easier to do, not more effective, not more interesting, and not fully accessible compared to face-to-face evaluations. The advantages of online learning evaluations according to lecturers and students are that the scoring was perceived to be more objective, and online learning evaluations were considered as capable of increasing creativity and training students' thinking skills.
\end{abstract}

Keywords-Profile, Perception, Online Learning Evaluation, Covid 19 Pandemic

\section{INTRODUCTION}

Almost all countries in the world face problems related to the Covid-19 pandemic, and Indonesia is no exception [1]. The Covid-19 pandemic has impacts on all fields including education. Due to the Covid-19 pandemic situation, the Indonesian government has applied physical distancing as a coping method for the society [2]. Physical distancing which must be undertaken leads to a methodological change from students' classroom-based learning to learning from home [3]. The primay choice of learning in the Covid-19 pandemic situation is through the application of distance learning (DL). DL is a learning approach executed using technological information by making use of the Internet facility, and the learning processes are not in a face-to-face mode [2].

The most prominent characteristic of DL is that it facilitates and makes flexible for lecturers and students in determining online learning schedules without taking account of locations [4]. In the processes of DL, various platforms can be used effectively including applications, websites, social networks, or the learning management system (LMS). The platforms are utilized by lecturers to help facilitate learning as the media for material delivery, assessment, or just submission of assignments. A study conducted by Gunawan, et al. (2020) showed that all LPTK lecturers in Mataram carry out online learning during the Covid-19 prevention period by using a social media application such as WhatsApp.

An important part of the learning process in terms of both DL and face-to-face modes is the learning outcome. Learning outcomes can be measured through evaluations of learning. Evaluation is the process of clarifying what should be as desirable and comparing it with what actually occurs, for the sake of facilitating evaluative decisions about success and how to achieve such success [5]. More comprehensively, Mulya, et al. [6] explained that learning evaluation is part of the teaching system that extends to input, process, and output with all components therein. The principle of evaluating learning outcomes must be valid, educational, competency-oriented, fair, objective, open, sustainable, comprehensive, and meaningful. Also, online evaluation of learning is defined as the process of determining the values of students' learning through assessment and/or measurement of learning outcomes undertaken online [7].

The application of DL encourages that the implementation of learning evaluations is carried out online. Thus far, the learning evaluation having been implemented manually at tertiary institutions is considered identical to many of weaknesses as follows: 1) it requires a lot of time and money to produce the instruments; 2) it requires considerable time for processing and grading; 3) the checking processes of evaluation and feedback provision are time consuming; and 4) psychologically, such a manual evaluation often leads to the increase in test takers' anxiety due to the presence of supervisors around them, the conditions of other test takers, and environmental conditions [8].

Evaluation plays a very critical role in learning. The accuracy of data as regards students' abilities or students' difficulties in learning activities is highly dependent upon the 
accuracy of evaluation tools and processes carried out [8]. The purpose of learning evaluations is to determine the effectiveness and efficiency of learning system which subsumes objectives, media, materials, methods, learning resources, environment, and the assessment system per se. The specific objectives of learning evaluations are adjusted to several types such as comprehensive program evaluation, planning and development evaluation, impact evaluation, monitoring evaluation, and economic efficiency evaluation [9].

Online learning and its evaluations are also implemented at Universitas Samawa. This university does not yet possess the data associated with the implementation of online learning evaluations undertaken by lecturers. As a matter of fact, such data will be very helpful for making policies in the following semester, considering that the end of Covid-19 pandemic cannot be certainly predicted. Hence, this condition calls for the readiness of this tertiary institution to be adaptive. Through this study, it is expected that information regarding the implementation of online learning evaluations at Universitas Samawa can be elicited. The purpose of this study is to describe lecturers' and students' profiles and perceptions of learning evaluation activities carried out online.

\section{METHODS}

The present study was conducted at Universitas Samawa located in Sumbawa Regency of West Nusa Tenggara Province. This study was executed after online evaluations of learning outcomes were carried out by lecturers during the Covid-19 pandemic period, namely in the even semester of 2019/2020 academic year. This study deployed a survey method. The data garnered were in the form of both quantitative and qualitative data. The quantitative data referred to respondents' evaluative judgments on the given statements according to scale 1 (disagree), scale 2 (partially agree), scale 3 (agree), and scale 4 (strongly agree). Besides, this study also worked with qualitative data in the form of responses given by the respondents through filling out questionnaires and focus group discussion (FGD) activities that incorporated all respondents. The respondents of this study covered the lecturers and students at Universitas Samawa. The respondents were selected using a purposive sampling technique with the consideration that they represented each faculty at Universitas Samawa. The lecturer respondents were taken with a percentage of more than or equal to $50 \%$ of the total number of lecturers in each faculty that implemented online learning evaluations, so the number of lecturer respondents was 30 people. Student respondents were 77 people represented the students from each faculty.

The data collection technique deployed questionnaires as the instrument filled out online using the Google form application to obtain information pertinent to lecturers' and students' profiles and perceptions of online learning evaluations implemented at Universitas Samawa during the Covid-19 pandemic. One set of questionnaire contained 19 statements negotiating lecturers' and students' perceptions.

The data analysis technique used descriptive analysis. The quantitative data analysis utilized the scores gained from the scales of lecturers' and students' perceptions in order to determine the percentages and conclusions with respect to the statements conveyed in the questionnaires. Subsequently, the qualitative analysis was done as the basis for determining lecturers' and students' perceptions of the implementation and results of online learning evaluations.

\section{RESULTS AND DISCUSSION}

\section{A. The Conditions of Online Learning Evaluations}

The conditions of online learning evaluations provided a depiction of platforms utilized by lecturers to evaluate learning. Learning evaluation activities could be carried out from respetive locations using a number of the existing platforms so that the activities could run well. The conditions of using online learning evaluation platforms at Universitas Samawa are presented as follows:

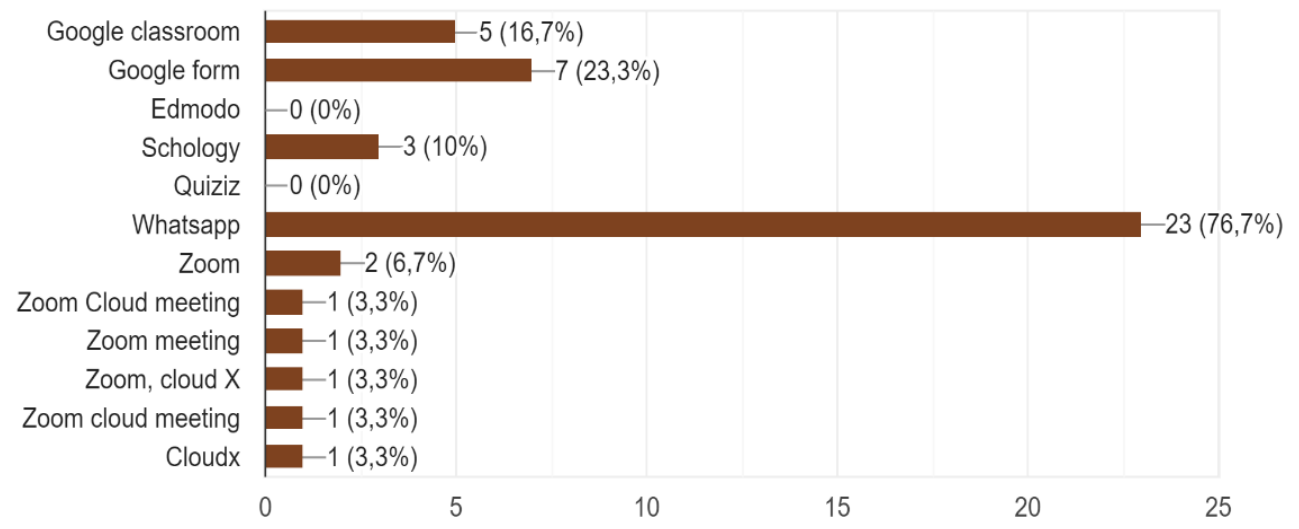

Fig. 1 The Platforms Used in Online Learning Evaluations at Universitas Samawa

The results showed that $76.7 \%$ of lecturers used the WhatsApp platform as an option for evaluating online learning. As the foregoing, the WhatsApp platform was utilized as a medium for sending questions, collecting answers within a specified range of time, and delivering feedback on the results of learning evaluations. According to respondents, WhatsApp was dominantly used because this platform was easy to use, portable in a way that all students had the WhatsApp application, practical, cheap, familiar, accessible to all students, simple, and easier to understand. The use of 
WhatsApp as a platform for evaluating learning outcomes at Universitas Samawa was aligned with the platform to conduct online learning during the Covid-19 pandemic, which also used WhatsApp. According to a study conducted by [10], 94\% of lecturers in NTB (West Nusa Tenggara) actively used the WhatsApp application for online learning. This application was chosen because both lecturers and students had this application on their smartphones, equipped with multichat or WhatsApp Group (WAG) features, making it easier for discussions to address lectures alongside enabling all WAG members to share files in a variety of types.

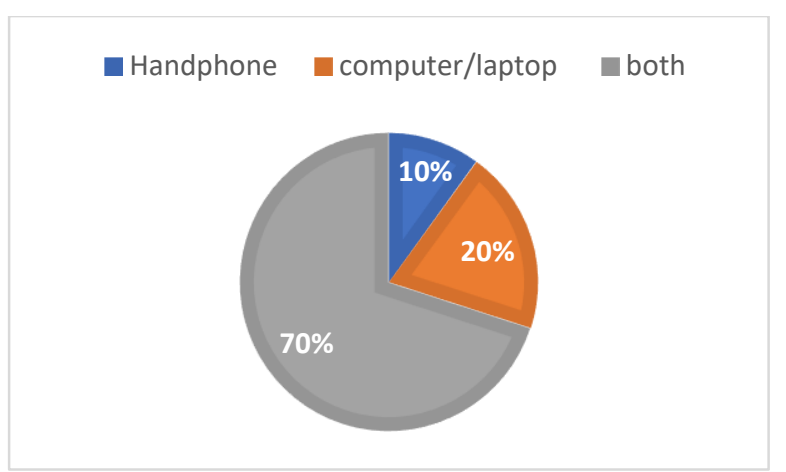

(a) Lecturers
Other data showed that $23.3 \%$ of respondents used Google form for evaluating students' learning. The use of Google form was to provide quizes with multiple choice questions. The Google form became the second most popular application chosen by lecturers at Universitas Samawa because it was considered easy to use, capable of saving evaluation time, and able to get real-time results. Nevertheless, the deficiencies perceived by lecturers in terms of evaluating learning using the Google form were that the preparation of questions slightly took time, and this platform was less effective in assessing students' understanding due to merely presenting multiple choice questions.

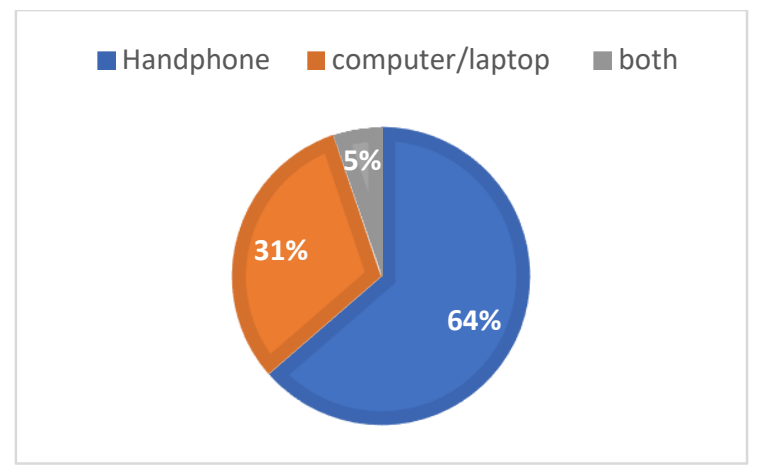

(b) Students

Fig. 2 Devices used for evaluations of learning outcomes

Access to online devices for the process of evaluating learning outcomes showed different conditions between lecturers and students. The use of devices in combination, namely laptops and handphones, was the most dominant amid lecturers, demonstrating $70 \%$ of lecturer respondents. A different case was found amongst students, where handphones became the main devices they used when dealing with evaluations of learning outcomes. This was because the students at Universitas Samawa on average did not have laptops so that the use of handphones was dominant. Besides, handphones were easier to use and more portable. The use of handphones has a major contribution in educational institutions, including the achievement of distance learning goals [11].

In respect of proficiency level in using devices and platforms, $60 \%$ of lecturers stated that they were proficient, while $27 \%$ of lecturers stated that they were quite proficient. The quite proficient percentages were shown in the use of platforms covering Google form, zoom, and schology. Students' level of proficiency exhibited that almost all student respondents were at the advanced to very advanced levels. As the foregoing, in terms of evaluating learning results, they used handphones and the WhatsApp platform.

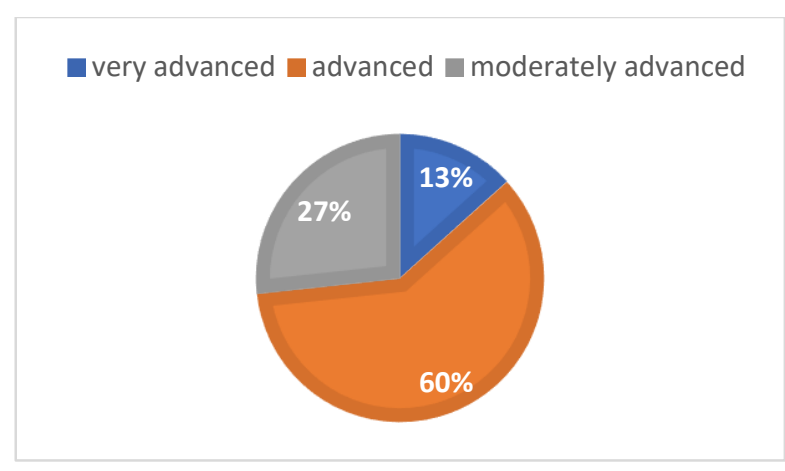

(a) Lecturers

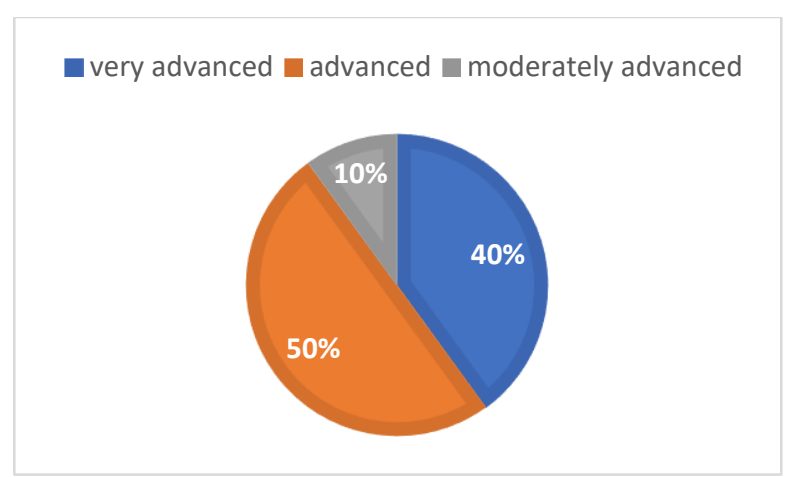

(b) Students

Fig. 3 Ability to Use Online Applications in Evaluating Learning Outcomes

\section{B. Perceptions of the Implementation of Online Learning Evaluations}

Perceptions in this sense referred to lecturers' and students' perceptions of the implementation of online evaluations during both midterm and final exams, the features of platforms used, the advantages of online evaluations, the obstacles and impedments faced, satisfaction with online evaluation results, and the provision of feedback as well as the accuracy of online evaluation results. Lecturers' and students' perceptions were 
assessed based on the implementation of learning evaluations (exams) carried out during the Covid-19 pandemic period, namely in the even semester of 2019/2020 academic year. The descriptions of lecturers' and students' perceptions could be viewed from several statements that the researchers negotiated via questionnaires as displayed in Table I.

TABLE I. TABLE TyPE STYLESPERCEPTIONS OF THE IMPLEMENTATION OF ONLINE LEARNING EVALUATIONS

\begin{tabular}{|l|c|}
\hline \multicolumn{1}{|c|}{ Statements } & \multicolumn{2}{c}{ Perceptions } \\
\cline { 2 - 3 } & \multicolumn{2}{c|}{ Students } & Partially agree \\
\hline Learning evaluations in an online mode are more effective than those of the offline mode. & Partially agree \\
\hline Learning evaluations in an online mode are more interesting than those of the offline mode. & Partially agree \\
\hline $\begin{array}{l}\text { Learning evaluations in an online mode are more easily conducted compared to those of the offline } \\
\text { mode. }\end{array}$ & Partially agree \\
\hline Learning evaluations in an online mode are not limited by space, distance, and time. & Partially agree \\
\hline Learning evaluations in an online mode can be reached by all students & Partially agree \\
\hline
\end{tabular}

From all statements negotiated to respondents, it could be identified that both lecturers and students partially agreed that learning evaluations in an online mode were easier, more effective, more attractive, and accessible compared to evaluations in a face-to-face or offline mode, except for the statement stating that learning evaluations in an online mode are not limited by space, distance, and time. For lecturers, the advantage of evaluating learning outcomes online was that it was very flexible because there was no need to take account of locations in addition to being able to be undertaken anywhere and anytime.

Based on in-depth interviews with respondents, learning evaluations carried out online could not run optimally due to several obstacles as follows:

The problem of Internet connection. The internet connection could not be predicted whether it would be working well or not during evaluations. The foregoing was especially for students who lived outside the city where the access to Internet was a major obstacle. When the policies of lectures and online examinations were carried out at Universitas Samawa, students on average returned to their respective villages. They had difficuleties in cellular signals in their respective villages. Even if there was an Internet signal, the signal that they could assess was very weak. This became a specific challenge in the implementation of learning and evaluations online.

Understanding of materials during online learning was not as effective as that of the face-to-face mode, so that many students experienced problems in solving the questions given during learning evaluations. Garrison and Cleveland-Innes (2005) reported that the higher frequency the lecturers come into the classroom and give explanations in online learning, the higher understanding of learning materials the students will acquire.

There was no uniformity in the use of platforms, and there were still found the lecturers who used platforms that consumed a lot of Internet credits such as Zoom, which was burdensome for students because they had to spend more to buy Internet credits. The use of Zoom as a platform of online learning has an advantage that enables direct interactions between students and lecturers, but it has weaknesses of being wasteful for Internet credits and less effective if there are more than 20 students (Naserly, 2020).

The duration of online exams was perceived shorter than that of face-to-face exams, especially if there were problems of Internet connection

The materials and the questions tested were sometimes inappropriate.

There was no any of prior outreach to students (the test takers) concerning the technical implementation of online exams.

\section{Dimensions of Questions and Feedback in Online Learning Evaluations}

Online evaluations of learning outcomes must be carried out as an effort to effectively prevent and mitigate the Covid19 outbreak which has now become a global pandemic. In the implementation of online evaluations, several obstacles are found because the system is new so that the implementation is quite problematic. Based on experiences of lecturing online during the Covid-19 pandemic, most of the lecturers at Universitas Samawa chose WhatsApp as a platform so that the final evaluations of learning were consistently carried out. Online evaluations of learning outcomes had a special challenge. Diverse locations between students and lecturers when online exams were carried out made the lecturers unable to directly supervise students' activities during exams. In such a way, there was no guarantee that students were sincere and honest in working on the questions given. Students' perceptions of learning evaluations undertaken online are presented in Table II.

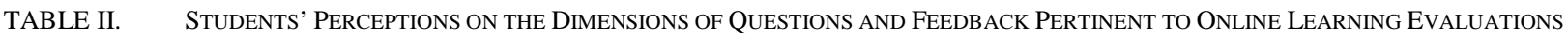

\begin{tabular}{|l|c|}
\hline \multicolumn{1}{|c|}{ Statements } & Students' Perceptions \\
\hline Using the online test makes me easier to solve the questions. & Partially agree \\
\hline Lecturers always discuss the test results. & Agree \\
\hline The difficulty level of online-based questions. & Moderately easy \\
\hline The suitability between the exam questions and the materials taught by lecturers. & Suitable \\
\hline Online evaluations that are carried out can measure students' mastery of the taught materials. & Partially agree \\
\hline Lecturers give scores objectively to students when evaluating learning online. & Agree \\
\hline Online learning evaluations can increase lecturers' and students' creativity. & Agree \\
\hline Online learning evaluations can consistently train students' thinking skills. & Agree \\
\hline
\end{tabular}


The results showed that according to students, in answering online tests, the time taken was not as short as that of face-toface tests due to Internet connection constraints, especially in villages with weak Internet signals so that the internet connections were often cut off, meanwhile the duration of exams was not extended. Students' delay in dealing with the questions of online exams was also due to their limited understanding of the tested materials. Although in general the exam questions were in accordance with the materials provided by lecturers, the problem was central to the lack of students' understanding of the materials provided by lecturers during online learning. According to students, understanding of the materials through learning carried out online was not optimal because sometimes the lecturers only sent the materials without providing the following explanations as what generally happened in face-to-face learning. Sometimes, the lecturers only provided the materials via the WhatsApp platform without explaining some points further.
In terms of the difficulty level of online exam questions, students considered it quite easy because some lecturers provided multiple choice questions with the answer choices already available. In addition, the opportunity for students to discuss or work with friends online out of lecturers' control was very possible because the supervision of the online exams was not as optimal as that of face-to-face exams.

The advantage of taking online exams for students was that the scoring became more objective, especially from lecturers who used the Google Form application in light of that the scores came out immediately after the exams were completely taken. In addition, most of the lecturers also discussed the exam results again. Online examinations were also considered capable of increasing creativity and training students' thinking skills. Aligned with the results revealed in Oknisih's (2019) study, online learning has the advantage of being able to foster self-regulated learning and increase creativity. The lecturers' perceptions of question dimensions are presented in Table III.

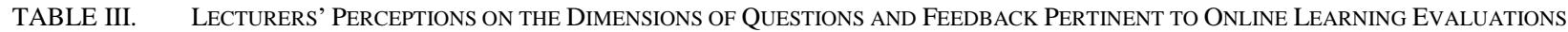

\begin{tabular}{|c|c|}
\hline Statements & Lecturers' Perceptions \\
\hline Delivering feedback during online evaluations of learning is easier to do. & Agree \\
\hline The online application helps in storing students' answer results for a later date. & Agree \\
\hline The online application allows lecturers to get real-time assessment data without having to use students' devices. & Agree \\
\hline Delivering feedback when evaluating learning online is done more quickly. & Agree \\
\hline Lecturers give fair values to students when evaluating learning online. & Agree \\
\hline Online evaluations that are carried out can measure students' mastery of the taught materials. & Agree \\
\hline Online learning evaluations can increase lecturers' and students' creativity. & Agree \\
\hline Online learning evaluations can still train students' thinking skills. & Agree \\
\hline Lecturers let students work individually or in groups when evaluating learning online. & Agree \\
\hline Lecturers let students access various learning resources when evaluating learning online. & Agree \\
\hline
\end{tabular}

Lecturers perceived that the implementation of online exams had many advantages in terms of question dimensions and giving feedback to students. Apart from being considered easier and faster in obtaining assessment results, online exams also made it easier for lecturers to obtain and store students' questions and answers for future needs because the data were stored in the system so that the data would not be lost and damaged. Through online exams, students' creativity and thinking skills could increase. The foregoing was perceived by not only students but also lecturers. Online exams also saved resources, such as saving paper and ink, energy, and time for lecturers to assess exam results, especially for those who used the Google form application. Students' scores could be obtained as soon as students finished working on the questions.

The weakness perceived by lecturers regarding online exams was the lack of optimal supervision of the exam implementation. In so doing, Students had great opportunities to collaborate with friends or access various learning resources during online exams. Cheating is something that frequently takes place even during the face-to-face or conventional exams. The use of online tests is inseparable from this problem as well. Online facilities also allow students to access information sources on the Internet, and this condition especially occurs when the tests are not centralized, such as in a computer laboratory. This condition makes the existing test results not reflect students' ability or knowledge.

\section{CONCLUSION}

The Ministry of Education and Culture's policy through circular number 4 of 2020 which contains directions on the processes of teaching and learning from home encourages that the evaluations of learning outcomes are undertaken through online teaching and learning. Universitas Samawa also implements midterm and final exams online through the use of several platforms in which WhatsApp becomes the most chosen platform for conducting online exams. Besides being easy to use and owned by all students, WhatsApp is also considered more practical, affordable, familiar, and accessible to all students. Lecturers' and students' perceptions on the implementation of online evaluations demonstrate that they do not agree with the statements stating that online evaluations are easier to do, more effective, more attractive, and accessible compared to face-to-face evaluations. The implementation of the online evaluations is considered less than optimal due to several obstacles such as 1) the problem of internet connection; 2) the level of students' understanding of learning materials; 3) no uniformity of the platforms used; 4) the duration of online exams which is noticeably shorter; 5) seemingly inappropriacy between the materials learned and the questions tested; and 6) no prior outreach pertinent to the technical implementation of online exams. Lecturers' and students' perceptions of online exam results demonstrate that the scores can be provided more objectively. Both lecturers and students agree that the supervision of online exams is not optimal, making possible that students work together in groups or 
access sources of information both online and offline to help them find the answers to the questions given.

\section{ACKNOWLEDGMENT}

The research team would like to thank the National Research and Innovation Agency (RISTEK-BRIN) that has financed activities regarding this study. The authors also thank the Institute of Research and Community Service (LPPM) at Universitas Samawa for facilitating the researching activities of the present study so that this study could be conducted properly. Also, the authors thank the lecturers and students of Universitas Samawa who are willing to become the respondents of this study.

\section{REFERENCES}

[1] Mardhia, D. Kautsasri, N. Saputra, L. I. Ramdhani, W. \& Rasiardhi, C.O. (2020). Penerapan Protokol Kesehatan dan Dampak Covid-19 terhadap Harga Komoditas Perikanan dan Aktivitas Penangkapan Indonesian Journal of Applied Science and Technology. 1(2). 80-87.

[2] Ramdani, A., Jufri, A. W., \& Jamaluddin, J. (2020). Pengembangan Media Pembelajaran Berbasis Android pada Masa Pandemi Covid-19 untuk Meningkatkan Literasi Sains Peserta Didik. Jurnal Kependidikan: Jurnal Hasil Penelitian dan Kajian Kepustakaan di Bidang Pendidikan, Pengajaran dan Pembelajaran, 6(3), 433-440.
[3] Herliandry, L. D., Nurhasanah, N., Suban, M. E., \& Kuswanto, H. (2020). Pembelajaran Pada Masa Pandemi Covid-19.JTP-Jurnal Teknologi Pendidikan, 22(1), 65-70.

[4] Bower, M., Dalgarno, B., Kennedy, G. E., Lee, M. J., \& Kenney, J. (2015). Design and Implementation Factors in Blended Synchronous Learning Environments: Outcomes from a Cross-Case Analysis. Computers \& Education. 86. 1-17.

[5] Williams, D., \& Graham, C.R. (2010). Evaluation E-Learning. International Encyclopedia of Education. From doi: https://www.researchgate.net/deref/http\%3A\%2F\%2Fdx.doi.org\%2F1 0.1016\%2FB978-0-08-044894-7.01643-2

[6] Mulya, R., Ambiyar, A., \& Wakhinuddin, W. (2020). Evaluasi Pembelajaran Online Berbasis Moodle Pada Mata Kuliah Sistem Operasi. Edukasi: Jurnal Pendidikan, 18(1), 39-49.

[7] Jauharul, F., M. (2016). Pengembangan Aplikasi Evaluasi Pembelajaran Online untuk Penididikan Jarak Jauh. Jurnal TEKNO. 26(2), 148-154.

[8] Setemen, K. (2010). Pengembangan Evaluasi Pembelajaran Online. Jurnal Pendidikan dan Pengajaran. 43(3), 207-214, from doi: http://dx.doi.org/10.23887/jppundiksha.v43i3.124.

[9] Arifin, Z. (2014). Evaluasi Pembelajaran. Jakarta: Direktorat Jenderal Guruan Islam Kementrian Agama RI.

[10] Gunawan, Yeni S. N.M., \& Fathoroni. (2020). Variations of Models and Learning Platforms for Prospective Teachers During the COVID-19 Pandemic Period. Indonesian Journal of Teacher Education. 1(2). 6170. 